Article

\title{
Sustainability in Early Modern China through the Jesuit Ac- commodation method
}

\author{
Inmaculada Rodriguez Cunill ${ }^{1}$, Miguel Gutierrez-Villarrubia, ${ }^{1}$ Francisco Salguero Andujar ${ }^{2}$ and Joseph Cabeza- \\ Lainez ${ }^{3, *}$ \\ 1 Faculty of Fine Arts. University of Sevilla. Calle Laraña 3. 41003. Sevilla. Spain. cunill@us.es, \\ rotwanghaus@gmail.com; \\ 2 School of Engineering, University of Huelva, Campus de El Carmen, 21007 Huelva, Spain. salguero@uhu.es \\ 3 School of Architecture, Dept. of Composition. University of Sevilla, 41012, Sevilla, Spain. crowley@us.es \\ * Correspondence: crowley@us.es; Tel.: +34-95-490-6793
}

bstract: With this article we would like to clarify the often-disregarded fact by virtue of which the European Missionaries in Asia acted as catalysts of a kind of nuanced acculturation named Accommodatio (adaptation). To a great extent they became harbingers of Culture and Science more than Faith itself to the dismay of many, including the Roman Church. Such cultural and scientific transference was actually two-pronged, for simultaneously they presented in Europe unique findings related to Language, e.g. the Chinese Characters (considered to be the sole natural language), Geography, Cosmology and even Governance. We would try to prove that such procedure contributed positively to the modern scientific notions of sustainability and to provide the kind of accoutrements that model the modern world as we know it.

Keywords: Asian architecture; Asian heritage; China; Japan; Urban Design; Garden and Landscape Design; Reformation of the Arts

\section{Introduction}

Arguably, due to a variety of circumstances the encounter of Western missionaries with the far East, particularly with China and Japan was in many ways different to that in the Americas. The political and social system, the warfare and moreover the cultural stance with a large Imperial Body of Scholars which mastered the ancient and paramount invention of printed word was considered to have evolved much more in East Asia than in the New Continent [1].

The Jesuits, an early presence in the area through the evangelization work of Francis Xavier [2] soon realized of this fact and acted in accordance. From the 1600's all the envoys to China had to be versed in Mathematics and Astronomy in order to be allowed to penetrate in that forbidden realm. Most of them had studied the famous Aula de Sfaera under magister Clavius, a rudimentary geometric system to decipher the misteries of the earthglobe and the sun movement, mainly intended for navigation.[3]

It is important to stress out that Xavier decided on his own will to pursue the evangelization of China as a prerequisite to fully attain the desired conversions in Japan, a fact that, paradoxically motivated his passing away due to illness and dereliction in the tropical island of SangChuan [2] (上川島)

In the wake of an epic pursuit, Matteo Ricci [4] (fig. 1) continued his ideal and performed a thorough process of acculturation that included writing in Chinese of a notable literary standard and being renowned as "the wise man from the West". He acknowledged the high level of erudition achieved by Chinese Confucian and Buddhist Scholars and often engaged in thorough discussion with their representatives and counterparts. Although it must be said that the premises were not alike for Daoist priests. [4] 


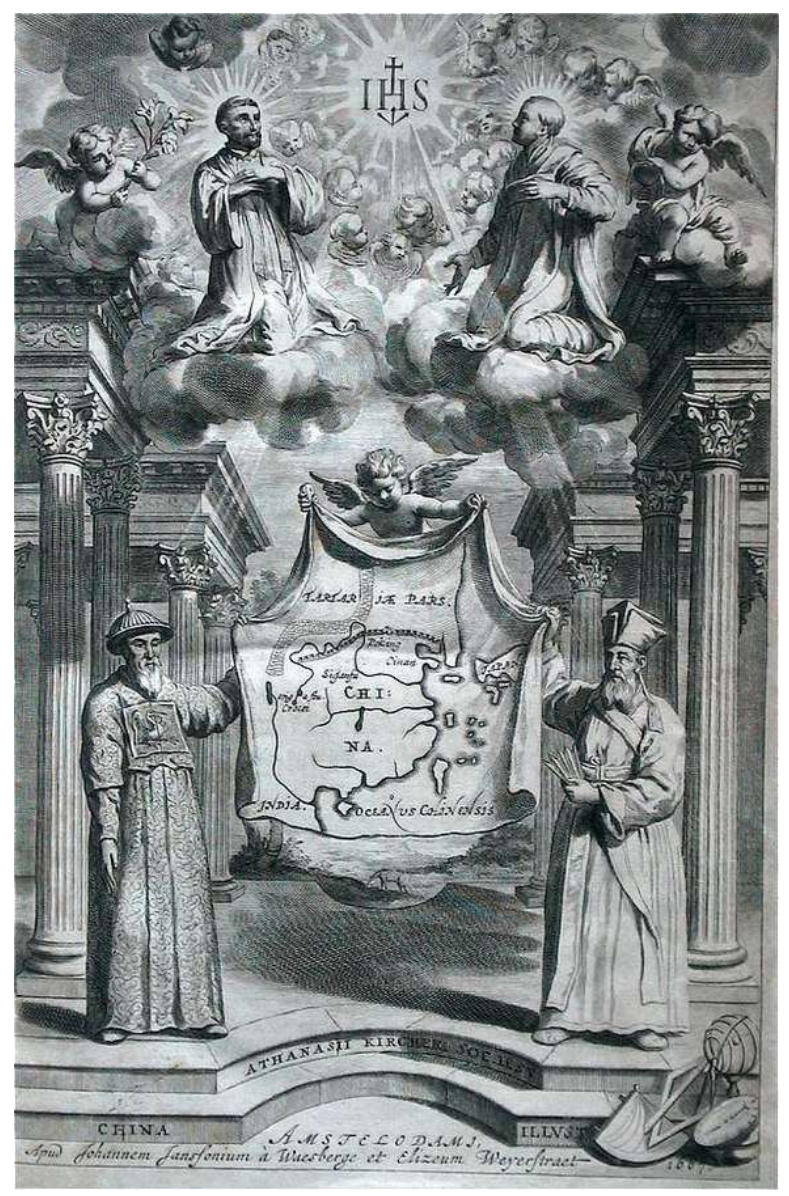

Figure 1. Adam Schall (left) and Matteo Ricci (right) holding the map of China. China Monumentis by Athanassius Kircher. 1667. Source: https://commons.wikimedia.org/wiki/File:Frontispiece_depicting_Adam_Schall_and_Matteo_Ricci_holding_a_map_of_China.jpg.

In their "Letters" (Lettera della Cina, Lettres edifiantes et curieuses) a complete body of knowledge is enshrined. Much can be gained from its detailed study [5]. These illustrated actions were undertaken in China, Japan, India, Tibet and Vietnam with outstanding results such us compiling a new quốc ngũu. (Vietnamese romanised language) by Alexandre Rhodes and his companions.

Other times, like in China, the missionaries erected temples, gardens and even palaces to the Emperor. [6] In Kyūshü (九州), Japan, several wooden churches now protected as heritage were built. [7]

The intellectual emphasis on the Jesuit's accommodation method derived not merely from his own intellectual inclinations, but also from what he perceived in the character of the Japanese and the Chinese. In the following pages we would describe how and why the whole process took place.

\section{Materials and Methods}

The town of Nagasaki (長崎) was pivotal in the enactment of acculturations hereby discussed and we would like to depict the territorial and urban reasons for this singularity. The enclave was Iberian in origin and foundation, but later developed in a Japanese fashion until today. (fig. 2)

The secular isolation of the Japanese archipelago, called by many sakoku (鎖国), which can be translated as "enchained country", implies that Western influences were not very deep or lasting and hence the originality of this town. 


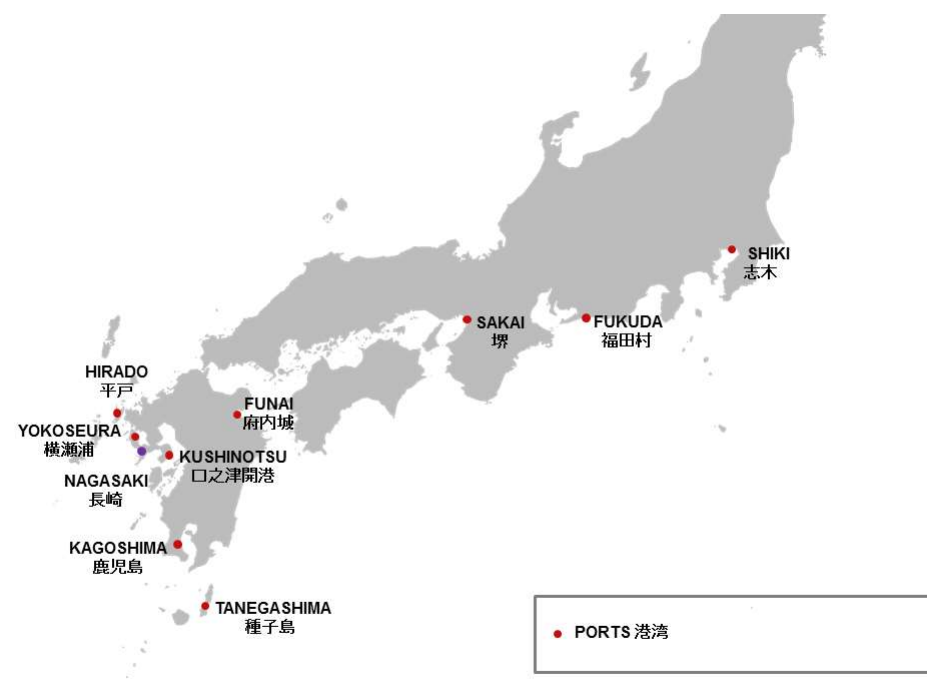

Figure 2. Ports used by Portuguese Merchants to trade with Japan. Source: Gutierrez-Villarrubia. 2021.

In fact, it is in Nanban bijutsu (南蛮美術) or Nanban Art and their moods, where the effervescence generated by the cultural encounter between East and West is reflected. Language terms [ pan (麺麭) bread, tabako(煙草) tobacco, marumero (榲桲) or quince], gastronomy and moreover artistic objects of great beauty become relics of a rich history in time.

How did the Japanese who were the first to be in contact with missionaries from Europe envision a brighter prospective? To answer this question, we have judged necessary to divide the explication into three parts:

\subsection{The Nanban paintings}

In the first place, we will focus on the Nanban paintings, literally the paintings of the 'Southern barbarians' (considering the typical Chinese division of the territory according to the four cardinal points), and how we can identify an early attempt to achieve a better atmosphere, thanks to the Japanese fascination for images brought overseas by the members of the Jesus Society.

The evangelization of the Jesuits brought forth an interesting process of acculturation, based on the premises of Accommodatio. The ingredients of Accommodatio were persuasion within a propaganda framework of images, essential to carry out the CounterReformation process. To perform this, the vow of obedience was necessary, but also to encourage the inventive capacity of the missionaries in adaptation to the customs of the people.

The instruction of these religious explorers included astronomy, arithmetic, geometry, geography, and training in instruments that would help to create maps.

In our opinion, the idea of Accommodatio has another very interesting aspect to understand the art produced by the Japanese, in relation to the concepts here discussed: transcendence. Not transcendence as a spiritual value encompassed in Christian beliefs, but in the very act of painting, where the right side of the brain is exercised and we are immersed, as creators, in a non-linear temporal concept.

The remoteness undoubtedly helps to convey the image of alien spaces, sieved through the lens of those who had never trodden on them, with a sometimes-fanciful bias, which gives us in turn, many clues about how a possible future was imagined. But in order to be aware of remoteness, it is first necessary to know that that other exists: such, no less, is the feat attained by the missionaries.

This method is in frank opposition to the colonizing frenzy that spread three centuries later on the whole planet. Today we refuse to accept the Eurocentric pride in the 
phrase "They cannot represent themselves: they must be represented". Seeing the other as an enemy prevents us to build a more sustainable world, as the famous etching Die Gelbe Gefahr (The Yellow Peril) depicts, even with a Buddha included in the background [8].

From mid16th century (1570), the Portuguese established the end-line of their trade route at the Nagasaki Bay. Shared art and techniques were positive products that endured, even after the short century of contact between the Jesuits and the Japanese people had ended.

When the Portuguese landed, the Kano school had achieved a new exaltation of idealistic Japanese art. In this context, an expedition began and would culminate in Japan. Francis Xavier (1506-1552) set sail from Portugal in 1541 bound for the East Indies. [9]

Japan had already experienced the first contact with Europe seven years earlier with the arrival of a Portuguese ship on the shores of $K y \bar{u}$ sh $\bar{u}$. In 1549, Francis Xavier alights on Kagoshima (鹿児島). Soon, he would realize that for the evangelization of the archipelago he would need to open up to the people and satisfy the questions of the curious Japanese individuals. [7]

In order to be allowed to preach, he could not present himself empty-handed before a daimyō (大名). He relates that the Christianized Japanese, Paulo da Santa Fe went to speak with daimyō Ōuchi Yoshitaka (1507-1551), 大内義隆 to whom he gifted an image of the Virgin. [7]

Francis Xavier's letters speak of the amazement of the daimyō with religious fervor, but the important thing about it, is that Xavier earns the respect of the Daimyō Ōuchi Yoshitaka with the sample of an etching of a surprising figurative level for the Japanese.

But after the amazement, the Japanese wanted to reflect those distant worlds by bidimensional means. The first screens painted with elements from afar were still made with Japanese techniques, in this case on washi (和紙 rice-straw) paper. They reflect an initial trend in which Japanese artists used traditional painting to describe large European cities. [10]

In the famous Nanban Byōbu (群風 folding screen) of Rome (fig. 3), it is easy to recognize the figures of important ancient monuments like the Pantheon and Castell Sant'Angelo near the Vatican. From the first objects and works that Xavier brought to Japanese lands, so much interest was aroused that a greater number of works was necessary for the evangelizing quest. They imported from Europe large amounts of engravings, oil-paintings, carvings and furniture for the decoration of churches and for commitments with powerful individuals as well. [11]

It is very likely that the references to depict those cities, came from the "guidebook" of the time, the book Civitates Orbis Terrarum, dedicated to the famous capitals of the world.

In three of these four screens, it is evident that the Civitates was used as a model, even in the screen of Lisbon, where the width of the image is narrowed to fit the frame, but the same point of view in the perspective remains. The last screen was dedicated to Istanbul. [12] 


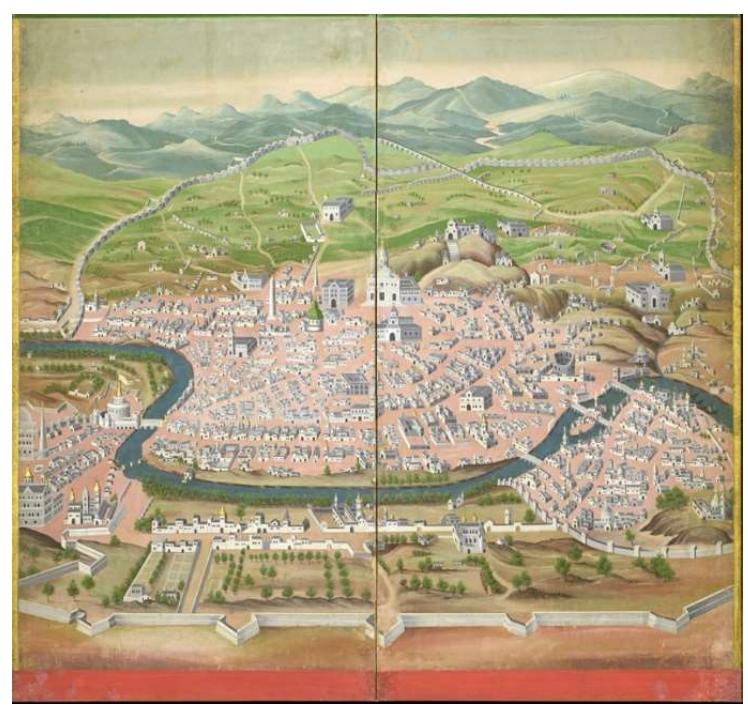

Figure 3. The screen representing Rome. Rome Byōbu (16 $6^{\text {th }}$ century). Ikenaga collection, Kōbeshiritsu Hakubutsukan (神戸市立博物館, Kobe City Museum). Source: https://artsandculture.google.com/asset/NQFF3EzEWIpZyg?ms=\%7B $\% 22 \mathrm{x} \% 22 \% 3 \mathrm{~A} 0.4489072652096861 \% 2 \mathrm{C} \% 22 \mathrm{y} \% 22 \% 3 \mathrm{~A} 0.8216624052897634 \% 2 \mathrm{C} \% 22 \mathrm{z} \%$ 22\%3A11\%2C\%22size\%22\%3A\%7B\%22width\%22\%3A0.4985233313644418\%2C\%22height\%22\%3A $0.33417465177011463 \% 7 \mathrm{D} \% 7 \mathrm{D}$.

This is not the case of Seville, which seems a tale apart from the four pictures that had been created throughout the different editions of Civitates. We can see how the Japanese culture itself was projected in the imagination of a city. As we know, the Latin name for Seville is Hispalis, which comes from the Phoenician root "pal", meaning 'flat'. And that is in truth a typical feature of this town. It does not possess any mountain range to protect it, as would be appropriate for the foundation of capitals in Chinese geomancy called Feng Shui (風水) or Hoggaku (方角 in Japanese. But the anonymous artist represented this new world as it would be coherent for his own culture. [13]

In that capitals that follow the prescriptions of Feng-Shui, the favorable orientation is extended towards the South, the city is protected from the North by soaring mountains, and defended by the East and the West through lakes or hills. There is a constant presence of the so-called Four Mythological Guardians, Four Heavenly Kings or Shitennō (四天王). [10]

With invented mountains (fig. 4), an enclave was imagined in this screen of Seville, that elicits the charm and wonder of combining East and West. Also, the construction and garrisoning of the city gates is endowed in East Asia with enormous significance and mysticism.

In summary, the author of these paintings made such renowned capitals remain protected according to his own imagination. This can be interpreted as an attempt to build a much more idyllic and pristine new world, since precisely the plague (and typhus) ravaged the city of Seville in five notorious outbreaks during the sixteenth century (1507, $1524,1568,1582$ and 1599) and the population was greatly decimated. We often wonder if its disposition, so contrary to geomancy, which eventually embodies a considerable degree of traditional building lore, had something to do with the said epidemics. 


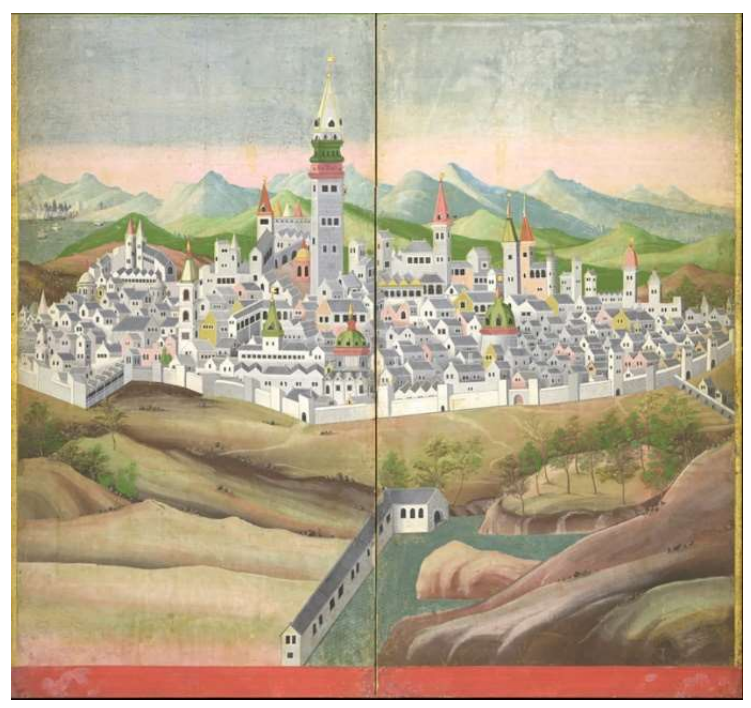

Figure 4. The view of Sevilla in one of the Four known Nanban Screens . Seville Byōbu (16th century). Ikenaga collection, Kōbe-shiritsu Hakubutsukan (神戸市立博物館, Kobe City Museum).

Source: https://artsandculture.google.com/asset/NQFF3EzEWIpZyg?ms=\%7B\%22x\%22\%3A0.4489072652096861\%2C\%22y\%22\%3A0.8216624052897634\%2C\%22z\% 22\%3A11\%2C\%22size \%22\%3A\%7B\%22width\%22\%3A0.4985233313644418\%2C\%22height \%22\%3A $0.33417465177011463 \% 7 \mathrm{D} \% 7 \mathrm{D}$

\subsection{Nagasaki, towards a Nanban Urbanism?}

It is in the founding and evolution of the town of Nagasaki where acculturation between East and West materialized more deeply. Located in a natural haven of Kyūshū Island, it lies in the southernmost of the five main islands of Japan.

Shortly after arriving on Japanese soil for the first time (1542), on the tiny southern island of Tanegashima (種子島) (the main reason why they were called Nanban, or southern barbarians), Portuguese merchants began trading with existing ports, such as Hirado (平 戸)，Funai (府内)，Yokoseura (横瀬浦), Sakai(堺)，Fukuda(福田)，Yamaguchi (山口)，Kagoshima...

However, none of these enterprises was in the end auspicious, due to several misadventures namely, typhoons, fires, riots or clashes between different daimyō and so forth. [7]

But to understand the tenacity of the Portuguese peddlers, we must realize that, for first time, the Earth had been interconnected through the Spanish and Portuguese routes, linking distant cities around the globe like Seville, Lisbon, Goa, Macau, Acapulco or Lima. For them, Japan and especially Nagasaki were a necessary step to complete the circle.

And why was the relationship between the Iberian-Europeans and the Japanese successful? Europeans aspired to global hegemony, not always through religion or straight conquest, but also through international trade. [8]

In addition, the Catholic Faith also sought for evangelization of the lands that they already encountered, through missionaries like the Jesuits.

The Japanese, for their part, were also interested in trade, especially for technological advances, which could also incline the balance in favor of some daimyō in a feudal period like the Sengoku (戦国) era.

All this would culminate with the founding of the city and port of Nagasaki between the two cultures. On the one hand, the Daimyō Ömura Sumitada (大村純忠, 1533-1587) and Bernardo Nagasaki Jinzaemon Sumikage (甚左衛門炭影). On the other, the Portuguese merchants and the Jesuits Luis de Almeida (1525-1583), Cosme de Torres (1510-1570), Gaspar Vilela (1526-1572), Alessandro Valignano (1539-1606), Luis Fróis (1532-1597) and others. The first, in charge of the justice, the second, of teaching and trade. Both entwined to plan a new city. [12] 
Let us discuss what urban imprint formed as a result in this hybrid city. As mentioned above, traditional Japanese urban planning is based on the precepts of Chinese Feng Shui geomancy, where it is mandatory to face south, the direction of Shujaku (朱雀) the Crimson Phoenix, and be protected to the East by Seiryū (青竜) the Turquoise Dragon, West by Byakko (白虎) the White Tiger and from North with Genbu (玄武), the Mysterious War of Tortoise and Serpent, while Kōryu (黄龍) or the yellow dragon stayed hidden at the center. [14] These Mythological Creatures, represent in turn the Shitennō. There is also an inauspicious direction to the northeast called kimon (鬼門, which must be protected by mountains and singular temples. (fig. 5)

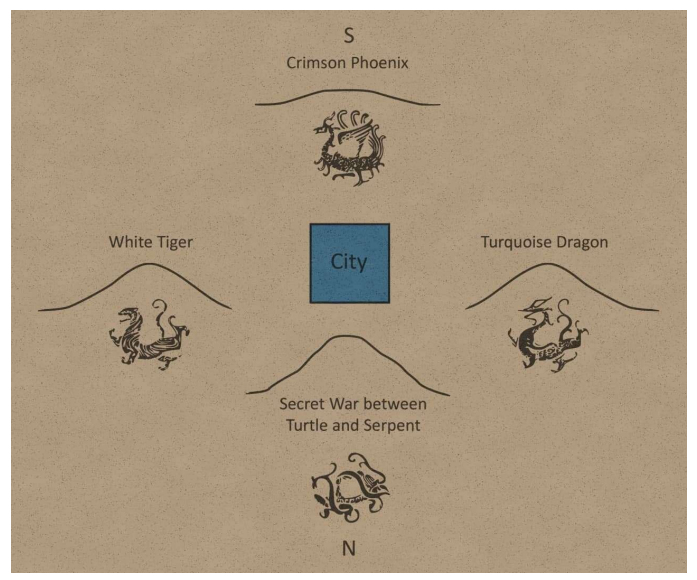

Figure 5. Orientation of a building or town according to Feng-Shui. Design by Gutierrez-Villarrubia. 2021.

The so-called diagram of the Nine Palaces, Nine Halls Diagram or Jiǔ gōng tú (九宮 圖) composed by nine square blocks, is also important, since the plan of the cities will evolve from this structure. [14]

The archetypal city, based in the Chinese capital of Chang'an (長安), would usually be displayed on a plain in an orthogonal grid of lineal streets or machi (町), conceited by mountains to the North, East and West and open to the south. Machi worked not only as circulation and transit streets, but also as lineal public spaces and as places of identity as in our European neighborhoods. It should be symmetrical, like the human body, with the palace to the North as its head. The rivers should flow without altering their course, from Northeast to Southwest. The Chinese version has surrounding walls, but its Japanese versions mostly lack important defensive elements.

This Feng Shui urban plan can be observed in Japanese imperial cities as Nara (奈良) and Heian-Kyo (平安京), later re-founded under the name of Kyoto. [15]

But Nagasaki was to be very different from this. The grid still exists, though it becomes curvilinear and deformed. Mountains roughly surround it to the North, East, and West, and it is open to the South, but has little flat terrain, so it grows on a hill and not in a plain. The rivers run from Northeast to Southeast, but they are altered and crossed by stone bridges. (fig. 6) 


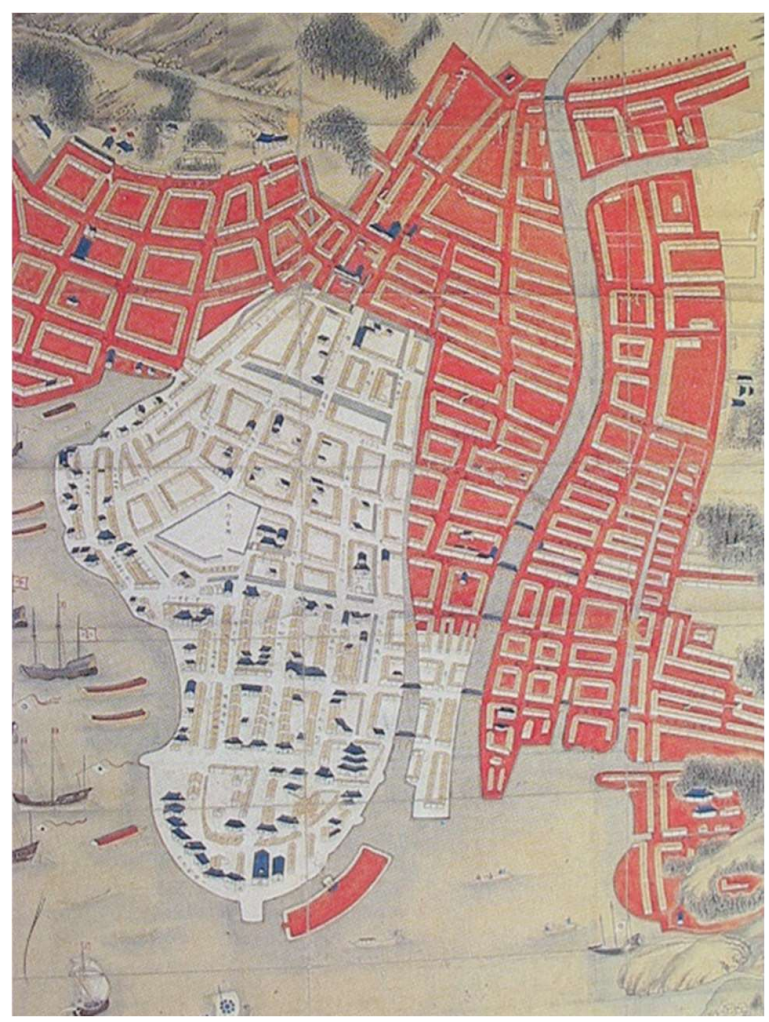

Figure 6. Nagasaki City Plan. Nagasaki Museum of History and Culture. Photograph by CabezaLainez.

Such was the legacy of Europeans: intricate streets, neighborhood organized in parishes around the churches. Stone foundations for seminars, colleges, hospitals, etc. Open urban spaces resembling squares and inner courtyards inside the blocks. A city protected at the harbor by some defensive structures.

That is the reason why we still define Nagasaki as "The least Japanese city in Japan" In only a century, (Table 1) the acculturation between East and West took place in a brandnew town at Southern Japan. But not only the urban plan of the city itself was a superlative example: western medicine, books printed in press, Japanese-Portuguese and Latin translations, and the Nanban Art all flourished there over the vanishing of the Christian mission. [16]

Table 1. Summary of the main events of the mission in Japan until its extinction.

\begin{tabular}{ccc}
\hline Period & Year & Event \\
\hline \multirow{3}{*}{ Sengoku jidai } & 1521 & Ashikaga Yoshiharu is proclaimed Shōgun \\
& 1526 & Go-Nara is proclaimed Emperor \\
& 1543 & Portuguese merchants wrecked in Tanegashima \\
& 1546 & Ashikaga Yoshiteru is proclaimed Shōgun \\
& 1549 & Francis Xavier reached Kagoshima \\
\hline Azuchi-Momoyama jidai & 1557 & Emperor Ōgimachi \\
& 1558 & Ashikaga Yoshihide is proclaimed Shōgun \\
& 1569 & Ashikaga Yoshiaki is proclaimed Shōgun \\
& 1573 & Nagasaki city foundation \\
& 1580 & Oda Nobunaga entered Kyōto \\
& 1586 & Arima's Seminary is founded \\
Go-Yōei
\end{tabular}




\begin{tabular}{ccc} 
& 1599 & Sekigahara Battle \\
\hline & 1603 & Tokugawa Ieyasu is proclaimed Shōgun \\
& 1605 & Tokugawa Hidetada is proclaimed Shōgun \\
Edo jidai & 1611 & Go-Mizunoo is proclaimed Emperor \\
& 1614 & Expulsion Directive Order to missionaries \\
& 1623 & Tokugawa Iemitsu is proclaimed Shōgun \\
1629 & Meishō is proclaimed Empress \\
& 1634 & Dejima island is built \\
& 1637 & Shimabara rebellion \\
& 1639 & Sakoku-rei \\
\end{tabular}

\subsection{Architectural inceptions from Macau}

To the Eastern Empire of China, the Jesuit Mission arrived by virtue of a misguided happenstance. Before accepting Christendom, the impassive Japanese Abbots inquired Francis Xavier about the reason why the Chinese Scholars had never mentioned Deus in their scriptures or treatises. [7]

Such tautological question provoked a hasty and inordinate evangelic streak that resulted in Xavier's own decease in the island of SangChuan (上川島) (the name derives from São João) at the very gates of Macau.

The deed was not in vain, since it heralded a new dawn for the Western Missions. In order to fulfil their foolhardy task, they had to inevitably face the grander, superior and more self-centred Empire that ever was. [14]

The first realizations that embodied these complex notions and kindred spirits, were the Madre de Deus Church also known as St. Paul in Macau (fig. 7), the Sao Lorenço church and later the St. Joseph Macanese Seminar.

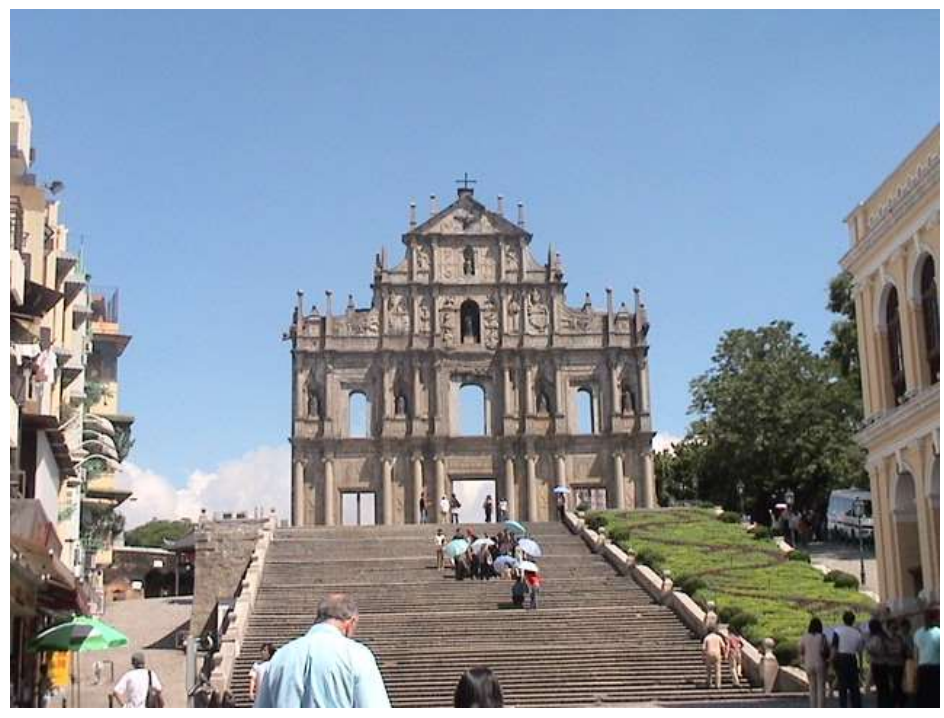

Figure 7. Extant façade of the Madre de Deus Church, Macau (Source: J. Cabeza-Lainez).

The Madre de Deus church was in all likelihood, the first clerical building made in stone in Asia [17] and as such it incorporated few innovations compared with European traditions. However, being erected in part by Japanese Christian who fled from prosecutions in Japan, in the façade we can recognise oriental motifs like the dragon of multiple heads and the lotus flower, deemed to provide spiritual protection from foes of any ilk.

Moreover, the orientation of the said main façade is South, what implies that it was adapted to the Chinese geomancy as explained previously. The western entrance, favoured in most European ancient churches was considered inauspicious and discarded by the Jesuits. [10] 
Another pivotal example of the adoption of Chinese cosmology in line with the Accommodatio method, lies in the dome of the Church of Saint Joseph in Macau (fig. 8)

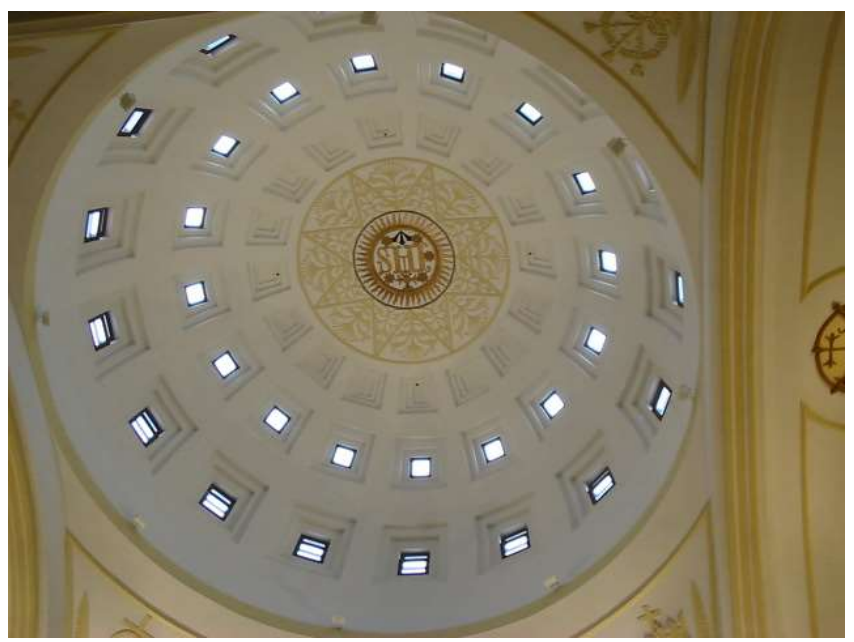

Figure 8. Interior of the illuminated dome of St. Joseph in Macau. Source: Cabeza-Lainez.

It is the authors' belief that the reason for avoiding domes in Chinese construction, was lack of confidence in the skills of local builders, which were not familiar with such uses of masonry or compressive materials and were more prone to employ wooden structures. Fear of weather, typhoons, earthquakes and other unknown phenomena may explain for the rest. [18]

The sky-lit dome, that is, the Triumph of Baroque Architecture in Europe, seldom featured in Asian Churches; in lieu of it, tall and delicately framed windows used to be the sole elements of fenestration.

However, in this graceful church of Saint Joseph [19] in a place almost secluded from the Chinese Empire the miracle of thirty-two tiny apertures in two tiers of sixteen, which echo the Houses of the Calendar of Beijing, both in disposition and number, reveals itself. A precious fusion of baroque from East and West only visible to the faithful who dared enter the Holy Space or Adytum

\section{Results}

All in all, these feisty endeavours engendered the so-called Chinese rites of the Catholic Church which attracted unabated political controversies and criticism as distant in time as 1950. Ditto rites precipitated the extinction of the catholic missions in China.

The Jesuits at the Qing Court (清) justly excelled in astronomical knowledge and subsequent prediction of time events by manufacturing watches, astrolabes and diverse mechanical tools of measurement for the Emperor [20]. This fact was elegantly inscribed in the Nantang (南堂) Cathedral in Beijing (see 3.2) with the fixture of two voluminous clocks at each side of the main façade towers, marking simultaneously the time in China and that of Rome. The former fact indicates that they had observed, by exchanging letters in the occasion of eclipses, the significant magnitude of the time-lag between both places, although they were still incapable of tracing a proper meridian (see 3.1). In fact, the NorthSouth line of the Celestial Horse called $W u$ 午, present at the entranceway to the Forbidden City, the Meridian Gate, which divided the Empire in two halves, was the only similar feature enforced at the time.

\subsection{The Horoscopium Catholicum Societas Iesu}

An evident witness of the long quest for terrestrial longitude in geographical sciences, is the prodigious mandala-like representation known as the Horoscopium Catholicum (Fig.9). 
The Horoscopium, attributed to the polymath Athanasius Kircher, [21] is a sort of global map and clock, conceived after the fashion of a family tree (sicut olive fructifera), at the roots of which lie the revered founder Saint Ignatius Loyola. The ascending branches naturally reach out for the sun and every bunch of leaves bears the name in Latin of a distant province and its tributary cities, that is, Hibernia, China or Iaponia and then, Nangasachi or Meaco (Fig.10).

The astonishing particularity is that the label tags of the provinces are constituted by semi-circular diagrams with successive number inscriptions in the fringe, which reveal with considerable accuracy at what Hour, compared to Rome, each Jesuit college of the world should be performing its prescribed activities.

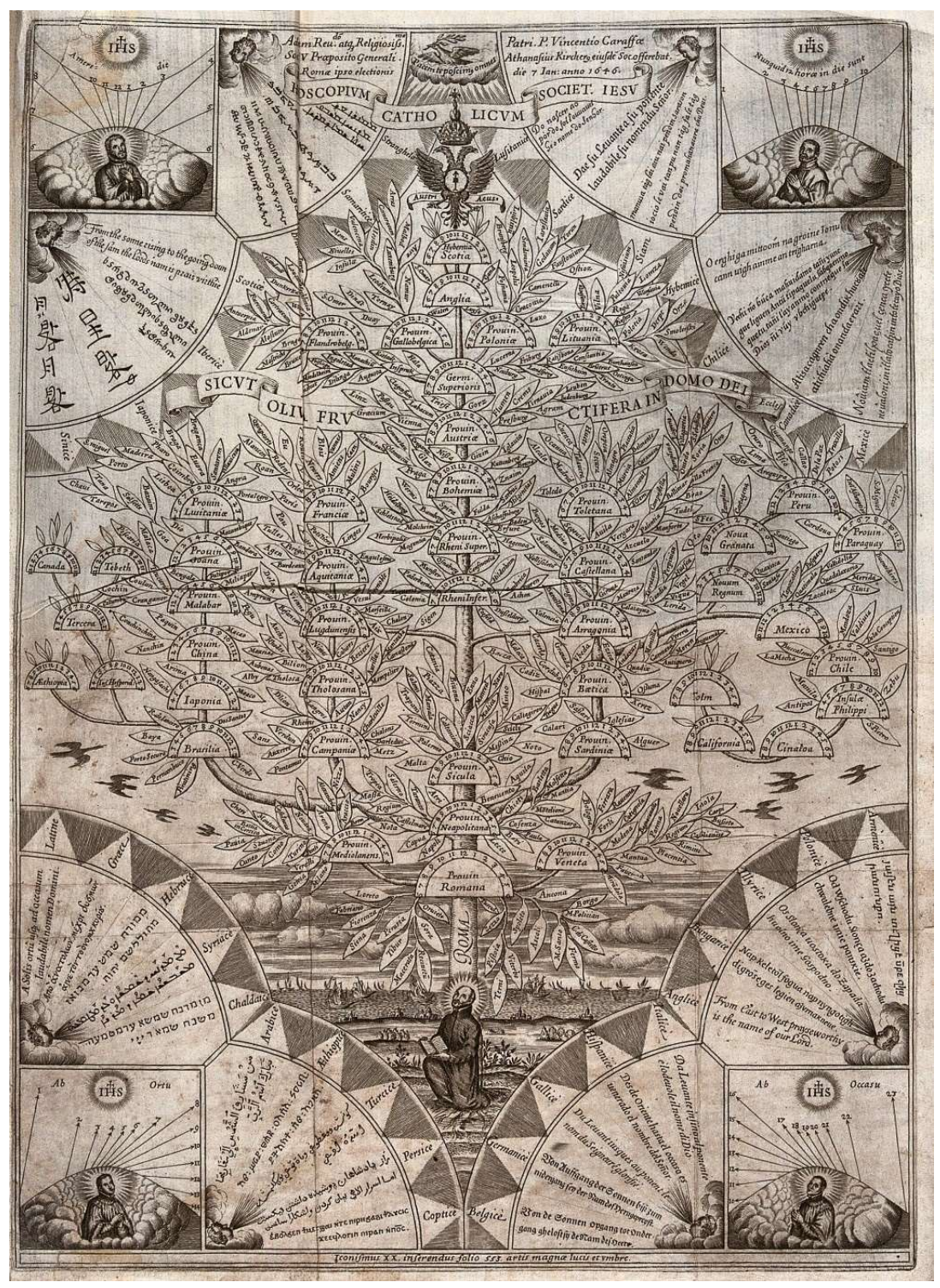

Figure 9. Horoscopium Catholicum Societ. Iesu (1646) Athanasius Kircher. Source: https://iiif.wellcomecollection.org/image/V0035361/full/full/0/default.jpg.

Moreover, at every corner of the map, the cardinal winds, each apparently presided by a Jesuit Saint, proclaimed the same sentence, "from the rising of the sun to the sunsetting, praised be the name of the Lord" (Psalms), in the different and often enigmatic scripts and languages of the sundry provinces. [22] 


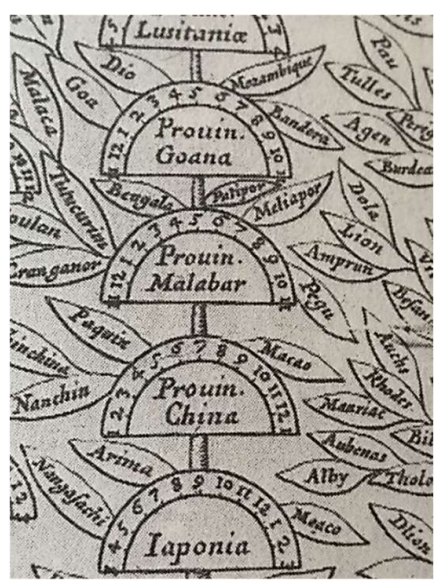

Figure 10. Particular detail of the Horoscopium featuring Japan and China.

In this tree-like representation we perceive a further advance towards Nature and Sustainability in the sense that the Society of Jesus begins to identify itself with a vegetal network ever growing like a climbing plant on fertile ground and not in barren deserts like those in North Africa or Arabia. The inspiration for this diagram in the new bountiful worlds is rather clear.

\subsection{The Southern Cathedral of Beijing}

The ensuing instance in the discussion, Nantang, is no longer an extant catholic church in Beijing. It was built by Jesuit Missionaries at the beginning of the 17th century, but suffered several disasters until it was ruined by the second Opium War in the 19th century. (Fig. 11)

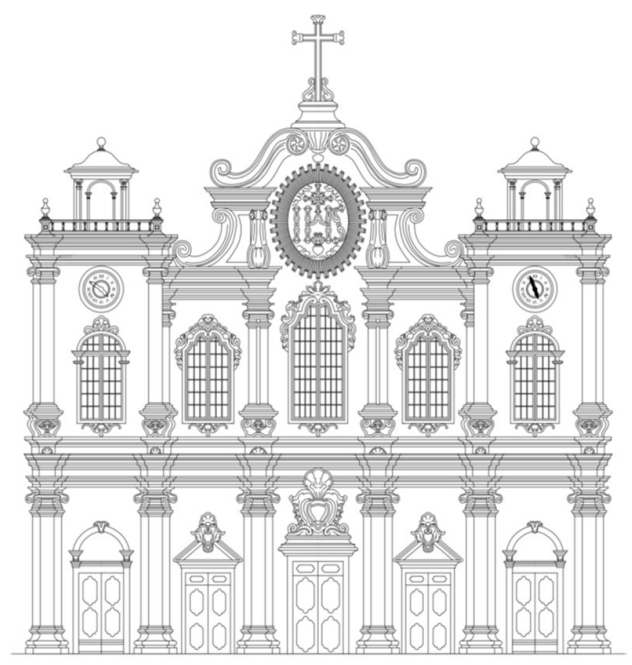

Figure 11. South façade of the Nantang Cathedral, reconstructed from the original plans preserved at the Arquivo Historico Ultramarino (Lisbon. Source: H. Ojeda and J. Cabeza-Lainez).

Later, a new rather nondescript church was erected on the same site, but it does not retain any of the excellent features that the former incorporated. The ancient church was a paradigm of sinicization, as we will try to demonstrate. (Figure 12). 


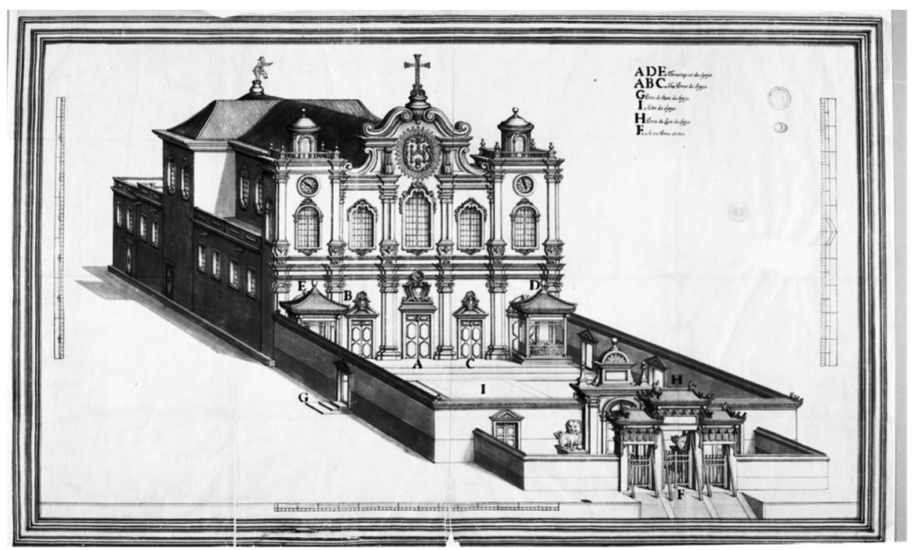

Figure 12. Cathedral's original perspective drawing by Ferdinando Moggi.. (Lisbon Overseas Archives). 1729. Source: https://artsandculture.google.com/asset/catholic-church-in-beijing/gAGbEWSfbZ2egQ?ms=\%7B \%22x\%22\%3A0.5\%2C\%22y\%22\%3A0.5\%2C\%22z $\% 22 \% 3 \mathrm{~A} 8.875930782235303 \% 2$ C\%22size\%22\%3A\%7B\%22width\%22\%3A1.7409347802985007\%2C\%22height\%22\%3A1.237518849 197432\%7D\%7D.

The Jesuits had prepared detailed plans and even a rarity, a perspective depiction (fig.12) in order to facilitate the construction of the church.

Many curious features appear in the original drawings that the Portuguese historic archives maintain today. One of them is the triple ceremonial gate flanked by stone lions to protect the building from evil appearances.

The plans present writings in Portuguese language, but complete inscriptions in Chinese also appear. One such inscription shows the cardinal points or directions of Heaven, as mentioned in Daoist scriptures, specifically indicating that the main façade has to face due south for the same reason of harmonizing with the cosmos and to avert calamities [14].

The overall style of the building did not resort to classic ornaments to resolve customary problems of expression, but rather seems to adopt baroque features like the stipite column as a starting point to create something new and capable of accommodating Chinese sensibility.

It is convenient to remark that the concept of jiān traditionally represents the typical module for buildings in China; a sort of cuboidal pattern that can be replicated bi-dimensionally. The jiān character (間) is etymologically composed of gate and sun. The main door of a building or even a certain town, had to face south as explained before to ensure that the sunlight filtered through it for most part of the day. This is the primordial function of the Toranas in ancient Indian architecture and the Torii gates of the Japanese precincts. Cycles of seasons evolved around such perceptual notion. Until the erection of Nantang, the door of a building in China, especially in a temple, was the sole source of light, in a disposition not unlike the cave. [14]

Because of their knowledge about the Aula de Sfaera the Jesuit-turned-scholars by Imperial mandate, knew the trajectory of the sun because they could easily calculate the latitude of any place with an astrolabe. By an entirely different procedure, they would also estimate longitudes as we have seen in the Horoscopium (figs. 9, 10) and the presence in the premises of the church of the twin-tower clocks attests. [23]

Apart from the façade, the features of the remaining walls do not present copious details. Nevertheless, from a different drawing, we know that the interior had gorgeous decorations, it possessed lierne vaults with sculpted and colored pieces of wood that embossed geometric motifs. (Fig. 13)

The Jesuits were capable of playing with a rare and precious building material: Light. For as Guarino Guarini had exposed, "the magic of insuperable wondrous mathematics shines brightly on marvelous and truly regal Architecture" [24]. 
The carefully positioned clerestories that the Jesuits designed on the south, east and west façades of Nantang became a marvelous eye-opener that contributed to lift the spirits of a cultivated elite of potential believers.

Such gift allowed for another unexpected instrument in which Giuseppe Castiglione (1688-1766) or, more properly, Lang Shining (郎世寧), a Milanese and arguably the last grand Chinese painter, infused his most treasured talent. It is on the inner walls of this Cathedral that the realistic murals of his creation were in display.

The admission of daylight on interior volumes, made it feasible to exhibit a plethora of images that would educate the converses in a more compelling way, without need for words or sounds. [25]

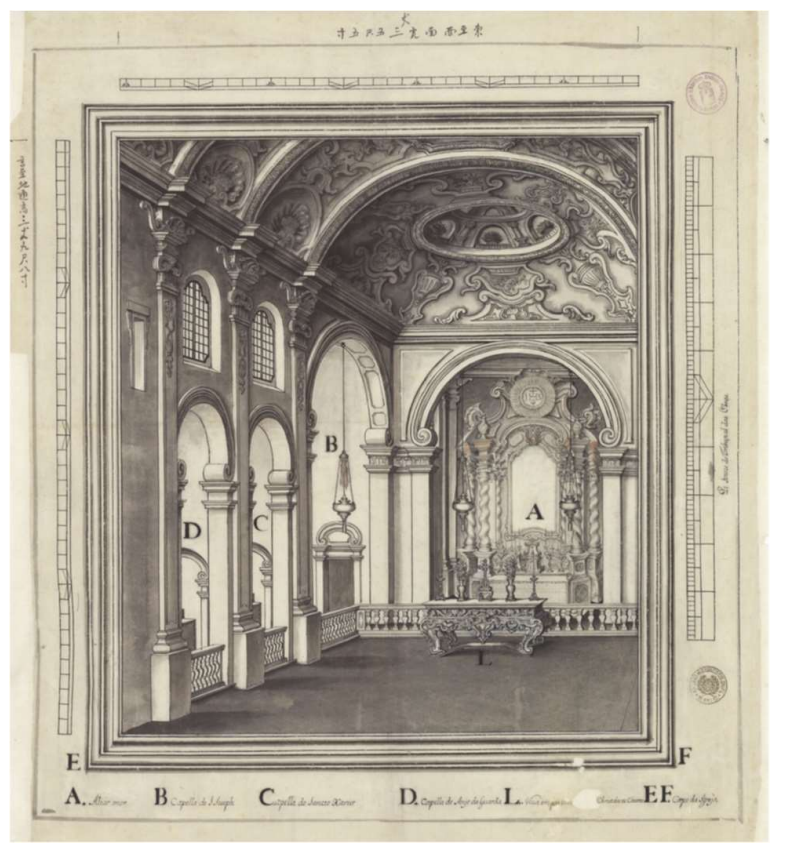

Figure 13. Nantang's Cathedral detail of the vaulted interior. Ferdinando Moggi. 1729. Source: https://artsandculture.google.com/asset/catholic-church-in-beijing/4wE7DBR2RMPLiQ

To ascertain the sustainability of a notable construction like the present one, we have simulated the building with the assistance of modern software, in terms of adequacy of orientation and distribution of daylight [18], obtaining the results presented in figs. 14 and 15.

The church possessed a nearly perfect orientation according to the current climate of Beijing; the decision to change the typical direction of the entrance to the south as prescribed by Feng Shui and other Chinese traditions can be evaluated as opportune and correct. (Fig. 14).

With respect to the lighting conditions the levels are very consistent especially on vertical surfaces with values of over 500 lux, in all seasons, which would imply an accurate visibility of the minute details of the frescoes executed by Giuseppe Castiglione.

Once this has been established, we can enter in the realm of subtleties by which the Jesuit decided to apply his mastery to illustrate the walls with scenes that might result appealing to Pekinese adepts in a sort of "mural" language. 


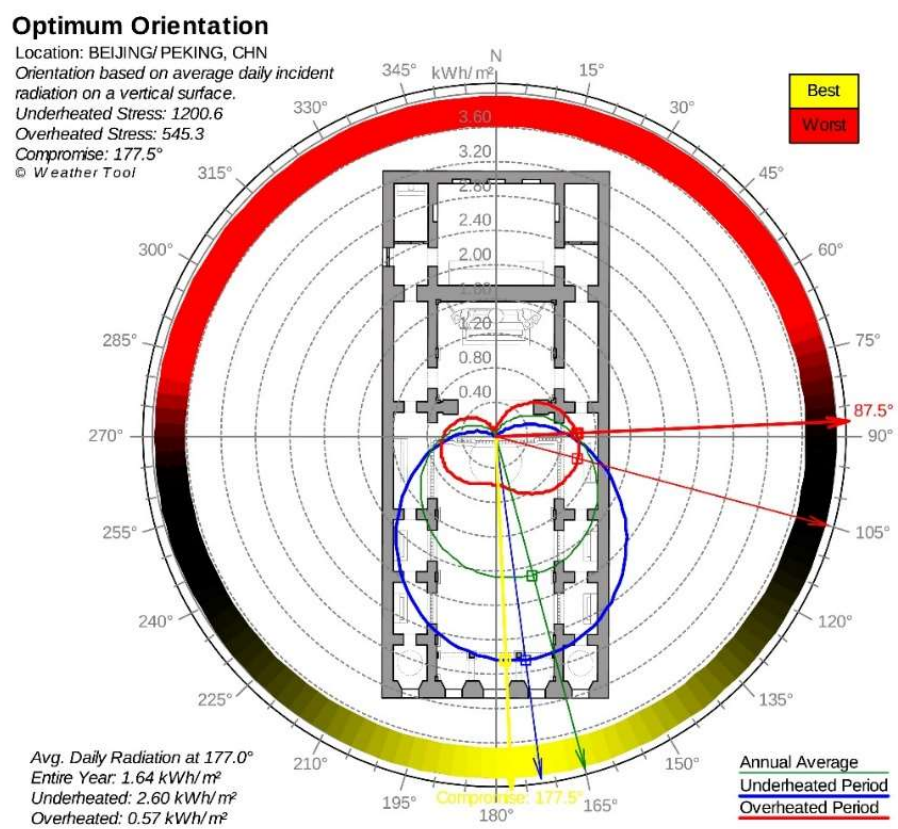

Figure 14. Evaluation of the plan of Nantang Cathedral taking into account solar radiation and temperatures in Beijing to determine the optimal orientation. Weather tool.

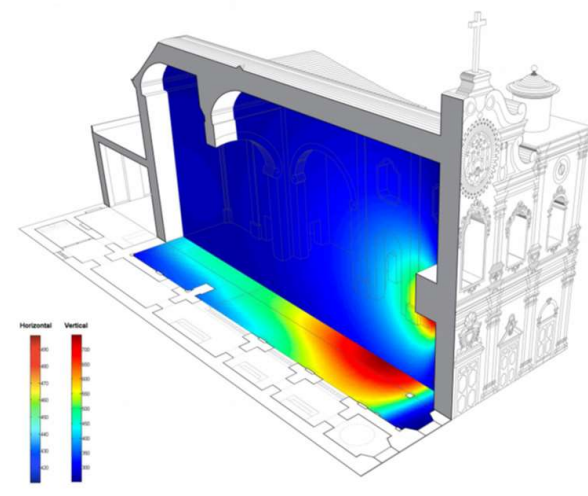

(a)

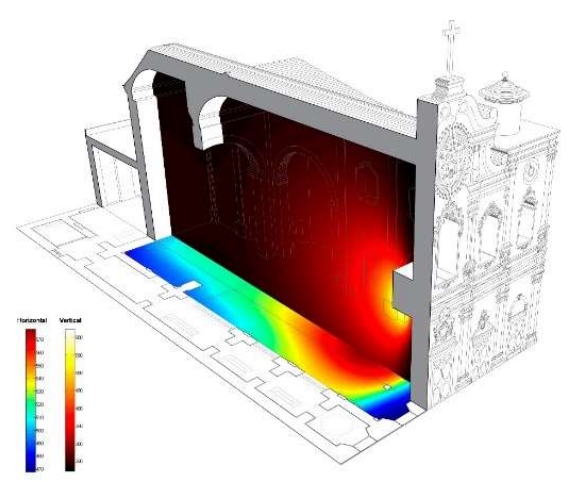

(b)

Figure 15. Light distribution in the Church in plan and section to evaluate the visibility levels: (a) Winter situation; (b) Summer condition. Source: Joseph Cabeza Lainez.

The process of introducing three-dimensional pictorial spaces in murals had been initiated in the Scrovegni Chapel by Pietro Aretino and later Giotto [26], Castiglione became familiar with the technique in Padova and then in his own apprenticeship at Genoa's cathedral [27], marbled in black and white 


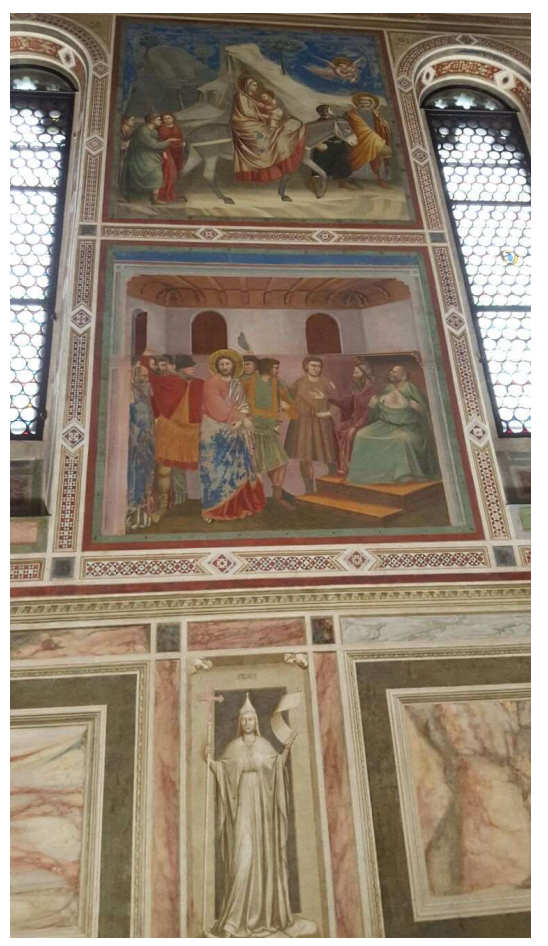

Figure 16. A fragment of the lateral wall of the Scrovegni Chapel, notice the frames with biblical scenes in perspective. Source: Cabeza-Lainez.

Stained glass and fenestration from early Renaissance periods introduced the practice of framing the void surfaces between windows and using them to depict sundry expedients related to the catholic liturgy, not merely limiting these effigies to altarpieces where the clerics would usually perform, but making them more accessible to the audience.

As we have seen elsewhere, framed pictures were unknown in the East and the same happened to canvas warp. The preferred fabric for painting was silk cloth and sometimes reinforced paper used in scrolls or folding screens. Both were not usually on display, but remained rolled or folded until a visitor required its opening for contemplation. The concept of permanent exhibition of Art in frames or murals was a complete and sudden innovation that the Jesuits incorporated for good in Asia.

Since the original Nantang was sadly razed, the only source to reconstruct the scenes conceived by Castiglione is a surviving text by Yao YuanZhi. His writings are amazingly accurate, so much so, that the authors have been able to objectively trace back much of the scenery that he described.

Yao wrote two texts about the murals. [28] We judged it important to transcribe the final fragment of the first one here: "the table within the room, if you see it at a certain distance is placed in perfect order and you would like to dwell inside but if you go for it you will realize that is only a wall!

"There was no perspective in ancient epochs. Since it is as accurate as this, you can only regret that our ancestors were not able to see it. That is why I had to record this tale."

室內几案, 遙而望之, 秩如也, 可以入矣。即之, 則油然壁也。线法古無之, 而其精 乃如此, 惜古人未之見也, 特記之。

The final line is important for the history of Art. Not only does it acknowledge the merits of the Artist but the lack of perspective drawing in China.

In figs. 17 and 18 different computer-graphics interpretations of the first text appear. 


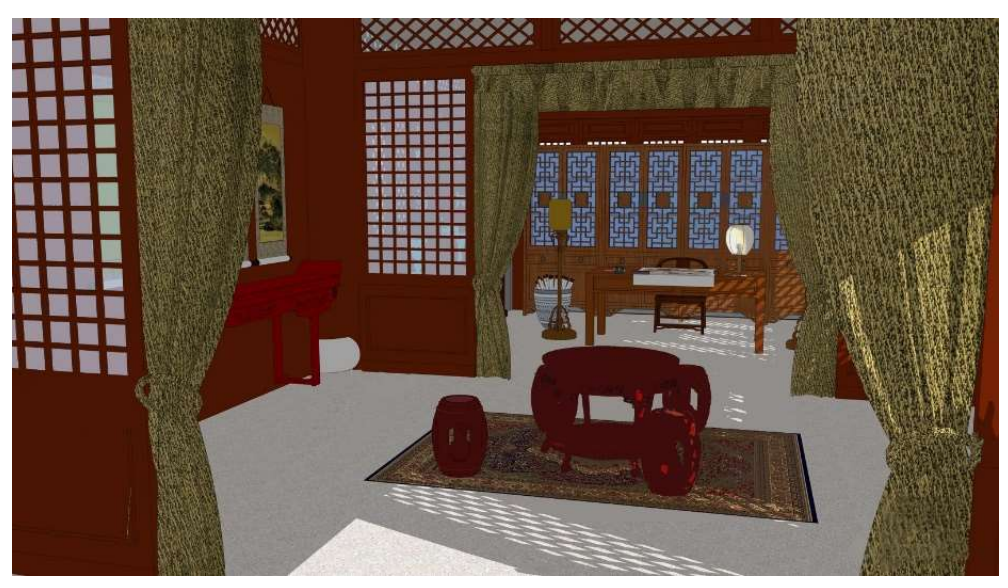

Figure 17. Digitally reconstructed detail of the first mural at Nantang featuring a Chinese chamber with typical objects in bifocal perspective. Courtesy of Yulu Yang.

The spaces and objects hereby represented are Chinese in a way, but they had never been perceived in this form, as for instance, they look much more ordered and perfectly lit than in reality. We believe that the reason for this stylistic audacity, is that Castiglione wanted to create an impression of proximity and lightness within the unfamiliar space of a western brick-and-stone robust church. Certainly he was not capable of producing a real Chinese building with filigree wooden elements but he would disclose it in such a way that Nantang may not appear as alien to their eyes by virtue of pictorial illusion. In compelling and astonishing the Chinese to the utmost with this miraculous recital of European Art and Architecture, the advantages of a new faith would be self-evident. [29]

Having arrived to this point we would like to remember that "Still Life" scenes are rarely considered in Japanese or Chinese traditional painting, Nature that comprises the Dao, must be represented teeming with life at all times [30]. If the Jesuits needed to impress the Court, such matters should be better avoided and an impeccable exercise in realistic perspective was to prove effective and reassuring at the same time.

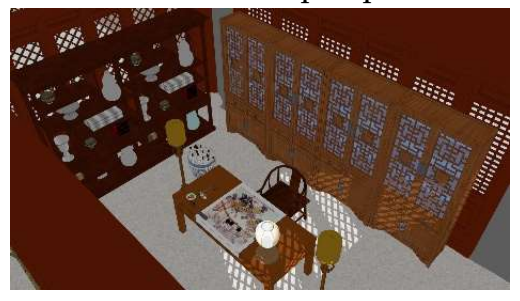

(a)

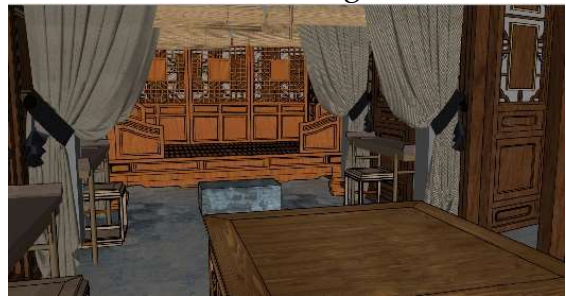

(b)

Figure 18. Different views of the chambers in a virtual approach to the first mural by G. Castiglione:

(a) Aerial perspective; (b) Reverse view of the main chamber. Courtesy of Yulu Yang.

The second fresco that Castiglione composed was more figurative. According to Yao, several celestial beings that we consider to be angels, saints and even the Virgin, intervene in a colourful tapestry in order to animate the scene. Perhaps this was a private concession to the Jesuit brothers who had missed such representations a long time, perhaps we would never know. We are working also in the production of an accurate rendering of this other mural albeit for obvious reasons it has proven to be a lengthy and exacting task.

As we have expounded, the artistic skills of the missionaries focused on works previously unnecessary to the Chinese, namely churches or even recreational divertimentos in the sphere of music, plays or architecture. Occasionally, geography and commented maps of the new worlds were on demand [31]. From time to time, an audacious treatise on mathematics, perspective or painting emerged.

This haphazard quest encompassed almost two and a half centuries (1582-1820), of patiently seeping and infusing European Sciences and Arts lest other more blatant 
procedures would bring forth turmoil and doom, which nevertheless surfaced nigh the end [32].

\section{Discussion}

In the last and most fruitful stage of collaboration and service of the Jesuits to the Empire, during the reign of Qianlong, Castiglione achieved an admirable synthesis which the Court seemed to appreciate. The first example appears in Fig. 19. The painter accompanied its sovereign to immortalize whatever events could happen in his august campaigns. Far from the capital, the royal throne could not benefit from the protection of mountains to the north. On that occasion, a piece of furniture with a marble slab that resembles a mountain was place at the back of the regalia. In this extraordinary painting Lang Shining reveals the supernatural in the natural, the Tao. We wonder how he could have become acculturated to such an extreme. [33].

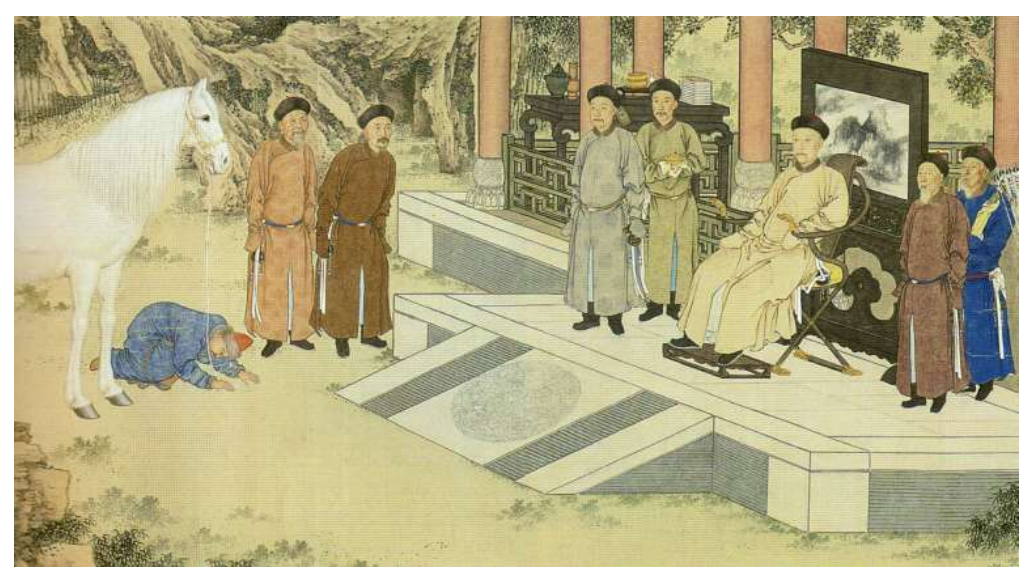

Figure 19. The Emperor Qianlong receives a tribute of horses from the Zhungars. G. Castiglione. Qing Dynasty. Guimet Museum. Source:

https://upload.wikimedia.org/wikipedia/commons/8/84/Qazak_pay_tribute_to_Qianlong.jpg.

Finally, we arrive to the complex of western style in the garden park of YuanMing Yuan, or gardens of perfect clarity 圓明園. Here a group of twenty feisty Jesuits did their best to demonstrate the quality of Christian Art. Apparently a set of twenty pavilions had been commissioned to Castiglione in the north-eastern corner of the YuanMing gardens, the Xiyang Lou 西洋樓 (Western Mansions) to lodge the ever expanding collection of curios and foreign pieces that the Emperor possessed.

It began with the Yuanying guan, 遠瀛觀 (Fig. 20), an observatory cum deck whose title translates as "the views of a distant ocean". Here again we contemplate the twin clocks together with an armillary sphere in the terrace of a splendid pavilion which featured white stone walls with faience yellow and blue tiles on the roofs. A complete architectural fusion of East and West which, while heralding surrealism for its spectral baroque strangeness, notwithstanding, showcased recent discoveries of Science in the matter of Cosmology. [34] 


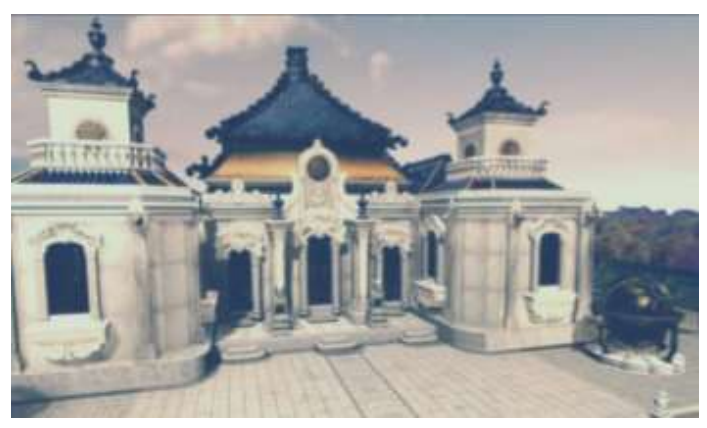

Figure 20. The Observatory known as YuanYing Guan in Beijing. G. Castiglione. Source: Photographs by Cabeza Lainez from the explicative panels of the site YuanMing Yuan. Beijing.

The former pavilion sublimely contrasts with the Haiyan Tang, 海晏堂 (Fig. 21), or pavillion of a Tranquil Sea, a splendid palace accessed through imperial curved stairs at the foot of which lies an ornamental fountain with twelve eerie animal figures dressed as Taoist sages. In fact, the basement of the palace is a massive water reservoir designed by Fr. Michael Benoist to induce jets and other hydraulic effects on the adjoining basin. [10]

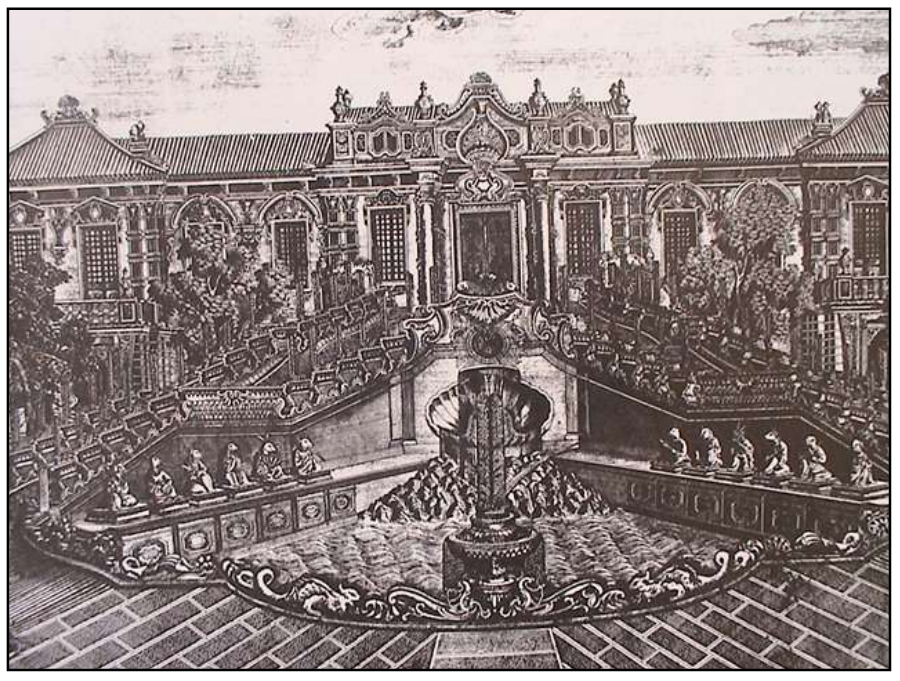

Figure 21. The pavilion of Haiyan Tang in Beijing. Source: Photographs by Cabeza Lainez from the explicative panels of the site YuanMing Yuan. Beijing.

Once again in this case, the extraordinary theme is not solely artistic or stylistic. The fact is that the Jesuits, paragons of modern astronomy in China, indulged in conceiving a grand water-clock in which the "hour-bell" would correspond with sprays of water from the heads of one of the twelve celestial branches of the Chinese horoscope.

Since ancient times, not only the years were named after this zodiac as we do now, but the hours of the day were marked by these mythical animals, being noon the horse 午, or meridian and midnight the rat 子. These hours lasted for one hundred and twenty minutes and thus their modern counterparts are called small hours. (小時)

Since the typical course order of the hours is, Rat (24h.) Ox (2h.), Tiger (4h.), Hare (6h.), Dragon (8h.) Serpent (10h.), Horse (12h.) Ram (14h.), Ape (16h.), Bird (18h.), $\operatorname{Dog}(20 \mathrm{~h}$.$) and Boar (22h.), and they do not appear in this way in the fountain, some$ scholars argue that the missionaries were ignorant and used these figures just as a mere decoration.

A more careful research conducted by Joseph Cabeza Lainez (fig. 22), reveals that the Jesuits were totally aware of the conventions. Only they had disposed the figures in two opposing wings to add on to the choreographic effect of the complex and facilitate hydraulic manoeuvres. [10] 


$\begin{array}{cc}\text { Ox丑 } & \text { Rat 子 } \\ \text { Hare 卯 } & \text { Tiger 寅 } \\ \text { Serpent } 2 & \text { Dragon 辰 } \\ \text { Ram } \text { 未 } & \text { Horse 午 } \\ \text { Bird 西 } & \text { Ape 申 } \\ \text { Boar 亥 } & \text { Dog 戌 }\end{array}$

Figure 22. The cosmological disposition of the Twelve animals in the fountain of HaiYan tang 海 晏堂. The hour of the rat is midnight and the hour of the horse is noon, the order alternates each wing of the basin to add movement. Source Joseph Cabeza-Lainez

It suffices to say that such finding results paradoxical indeed. The envoys who had precisely arrived to China to accurately predict calendar events, after a century long became transmogrified to the point of measuring time by means of the agonist's cosmological scheme.

In 1933 when modern architect Bruno Taut was forced by the Nazi regime to exile in Japan, he published two books on Japanese architectural culture. In them, being treatises on the vernacular, he had to address the question of geomancy and he drew the following graphic (Fig.23) which uses the same characters as in Fig. 22. He explained that these were the axis of superstition commonly employed to design every building in Japan.

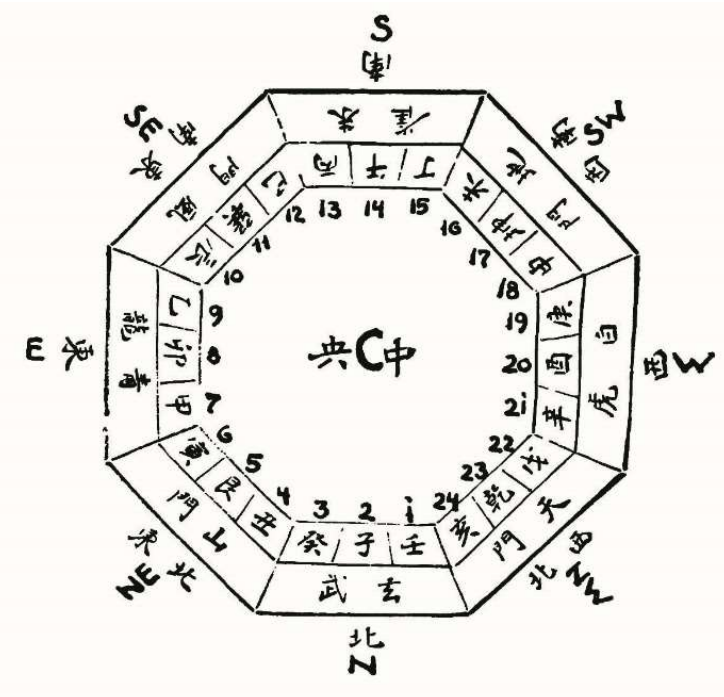

Figure 23. The same disposition reproduced by Bruno Taut under the title "Axis of Superstition". Notice that he deftly wrote the Chinese characters without having any idea of their meaning. Cabeza-Lainez.

Assuming in its entirety the Chinese cosmological system was one of the revealing feats achieved by the missionaries by means of their successful Accommodatio method.

Another would have been to experiment with bold new conceptions of space that defied the Chinese and Japanese notions which were based in strict modules of what could be realised in wood and consequently had not developed structures that could sustain massive loads like masonry, arches, buttresses or vaults.

In contrast, halls did arrange in China around empty spaces following cosmic schemes as the $b \bar{a} g u \bar{a}$ that often result in an imposed rigid geometry. As if humans tried to enforce their own intellectual concepts about order and harmony over nature. [14]

The spaces newly conceived by the Jesuits in China permitted the transmission of light to the core of the buildings, a boon that had never been achieved earlier in religious or representative architecture. 
Prior to that innovation, the temples often adopted a cave-like disposition similar to the hermits' abode in the mountains. It made no difference if the cave was an artificial creation in wood or stone as we find in many Buddhist sanctuaries throughout Asia (Fig. 24).

It is fair to say that the Jesuits' constructive systems freed Asian Architecture from the sombre petticoat of wooden post and rafter and its dubious sustainability especially in large-scale buildings. [18]

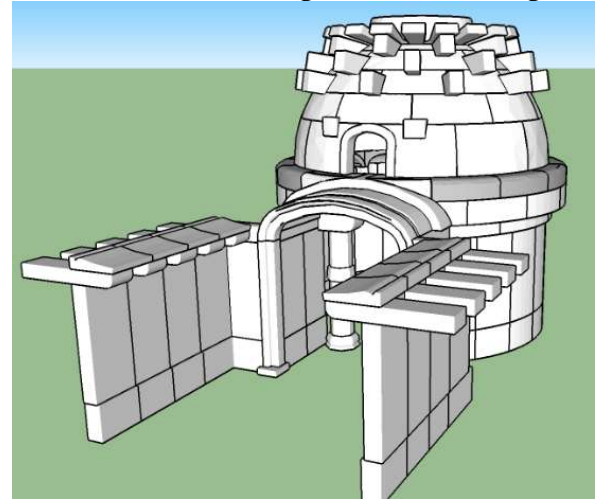

(a)

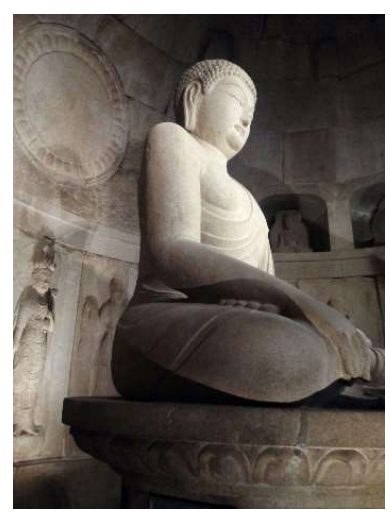

(b)

Figure 24. Outside and inside views of the Buddhist artificial grotto of Seokguram in Korea. Human Heritage Site: (a) Scheme of the cave-like temple with a suggested former opening; (b) Statue of the great Buddha on the inside. Source Francisco Salguero Andujar.

On the other hand, the missionaries had to take Nature in more regard and consideration, especially in landscape designs (Nagasaki) and open space enclaves like the YuanMing Yuan 圓明園, in fact the popular gardening style known in Europe as Anglo-chinois evolved from this melange of cultures throughout design. (Fig. 25)

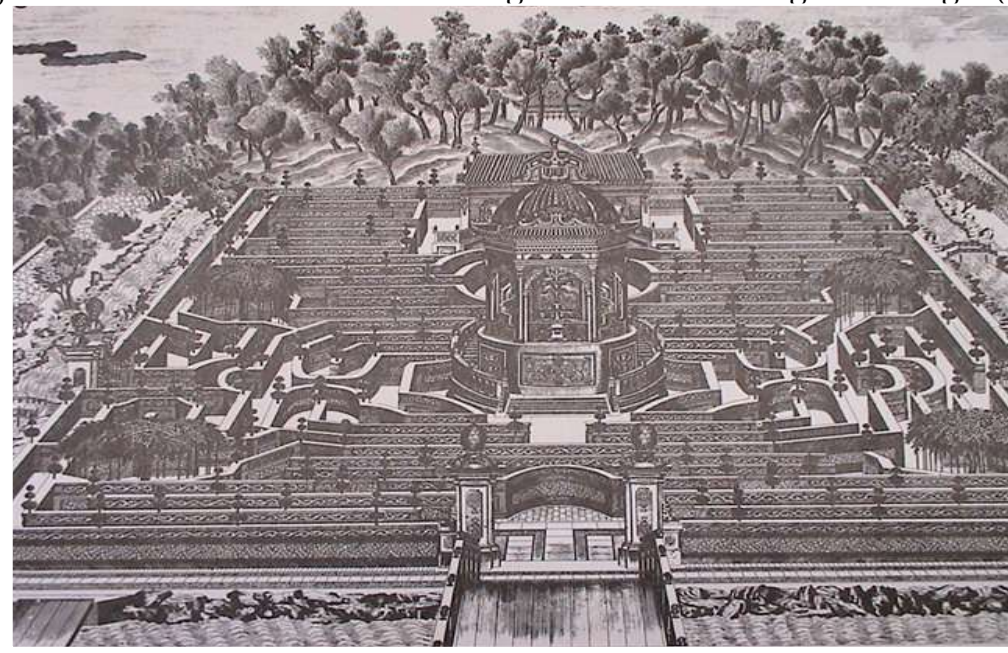

Figure 25. The surrealistic etching of the terracotta labyrinth in the YuanMing Yuan. 1783-1786. Source: Photographs by Cabeza Lainez from the explicative panels of the site YuanMing Yuan.

The Wanhua Zhen, 萬花陣, maze of one hundred flowers is an example of the architectural syncretism attained. It had to evoke hedge and mirth labyrinths common in European palaces like Versailles and Schonbrunn but instead, the central pavilion admitted a Chinese hipped roof and the scheme of the plan incorporated the Chinese numerology in nine circular rotundas (four for the cardinal directions, two for the vertical and three for moments in time, past, present and future). The surprising circumstance that 
it was made of terracotta and not of vegetal shrubs spared it from the devastation effected by Anglo-French troops in 1860. [34]

Traces of such interesting discussion reside in the celebrated poem of Bai Juyi (772846) "Climbing Mount Incense Burner" and its consequences for sustainability in advance [35].

"My new hut has three bays, and five columns, with stone steps and wooden pillars made of katsura tree. I put a door on the north side to let in cool breezes and to fend off oppressive heat; I made the southern rafters high to admit the sunlight in case there should be severe cold. The beams were trimmed but left unpainted, the walls plastered but not given a final coat of white. I have used slabs of stone for paving and stairs, sheets of paper to cover the windows; and the bamboo blinds and hemp curtains are of a similar makeshift nature. Added four wooden benches and two screen partitions. A serene brook traverses my piece of land but it rarely splashes out. Next spring, I will thatch the side room to the east; fit it with paper panels and reed blinds for my poems of Meng Guang."

$$
\begin{aligned}
& \text { 五架三間新草堂 } \\
& \text { 石階桂柱竹編牆。 } \\
& \text { 南簷納日冬天暖， } \\
& \text { 北户迎風夏月涼。 } \\
& \text { 灑砌飛泉緦有點, } \\
& \text { 拂窗斜竹不成行。 } \\
& \text { 來春更莫東廂屋， } \\
& \text { 紙閣蘆簏著孟光 }
\end{aligned}
$$

Master Castiglione, or Lang Shining in Chinese, deemed the last grand Chinese painter devised the European technique of focal perspective to illuminate and beckon the believers. At first he opposed frames to expanding scrolls but finally succumbed to the power of boundless expression to adorn the Imperial Chambers with the same spirit.

In the miraculous oeuvre of Giuseppe Castiglione at the Juanqinzhai (卷勤斋) the retirement palace of Emperor Qianlong (乾隆, 1711-1799), it is possible to admire a sublime reconciliation between natural life and abstract geometry by virtue of unifocal perspective. He painted an entire ceiling showing a bamboo arbour of hanging wisterias (holy flower of China) in full bloom (Figs. 26,27) [36]. Such was the astonishing Mural Language of Lang-Shining. Finally, a Universal Language much larger than Life.

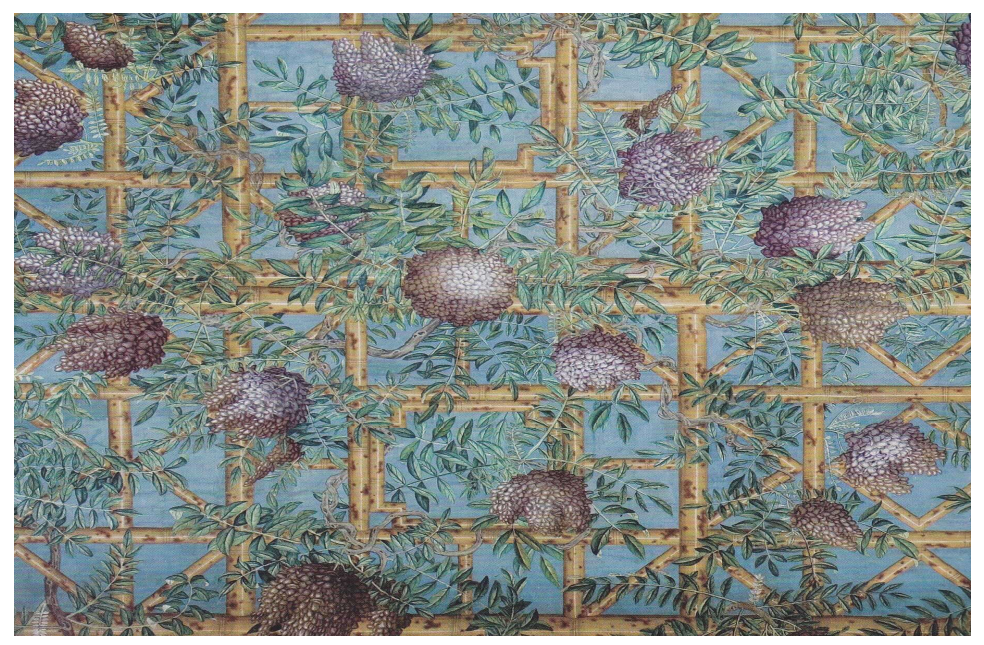

Figure 26. The wisteria arbour painted by Castiglione on the ceiling of the Juanqinzhai. Source: Cabeza-Lainez. 


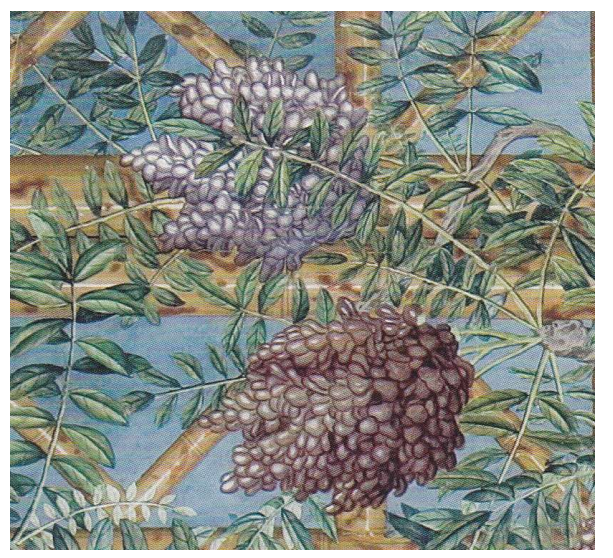

Figure 27. Castiglione, detail of the purple wisteria flowers.

\section{Conclusions}

A new type of Art, in harmony with European, Chinese and Japanese sources was engendered under the auspices of the Western Missionaries. In Japan such Art was named Nanban (after the Southern Barbarians). As for China it received no specific denomination but it is known that Sino-baroque gardening and architecture survived for decades in places outside East Asia, for instance in England, Germany or Turkey.

What brought these astronomers turned artists to East Asia is contained in equal

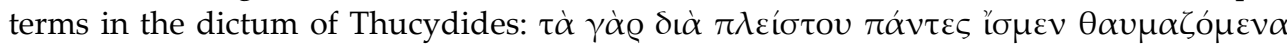

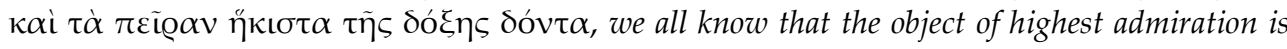
the furthest whose reputation cannot put to test [37]

Cross-cultural relationships did influence the development of empires, in all directions, based on what contemporary philosophers like Bucci-Glucksmann have justly called a "Baroque reason", which encompasses mathematics and geometry, art, science and literature. [38]

From the cultural point of view, the lessons that we should learn relate to Nature and the harmonious coexistence between the environment and civilization, almost to the point that it would be hard to tell the master from the disciple in these aspects. Realms appeared and faded in search of such elusive ideal.

In the Oriental Empire of China, which even now calls itself the Empire of the Centre (中国), parallel questions were poised through Daoist (道) numerology and geomancy, evoking the perennial symmetry of Nature also present in Japan. Eventually a fusion of horizons was attained.

For the unequal struggle towards Sustainability in the Modern World, the hypotheses and facts hereby exposed, appear both paradoxical and prophetic as hundreds of years have passed but still Human Culture seems at odds to sustain life on the planet. If something does not dovetail, how should we make amends?

As Watsuji Tetsurō (和辻 哲郎) once stated, the answer lies in that we can neither separate History from Climate nor Climate from History. Nature and Culture forking paths must ultimately entwine in inextricable though endearing Ways. [10]

Author Contributions: I.R.C. and J.C.-L. were helpful in conceptualizing the scope and issues of the article. J.C.-L. developed the main theories and introduced the Chinese characters. M.G.-V. was instrumental in visualizing the cultural and artistic implications of the task. F.S.A. brought the instrumentation and evaluated the available software.

Funding: This research received no external funding.

Acknowledgments: Inmaculada Rodriguez Cunill desires to honor the artists Eva Guil Walls and Maro Infante. She would like to thank Yulu Yang for her accurate renditions. Miguel Gutierrez Villarrubia would like to honour the rhapsode Jon Anderson. Francisco Salguero Andujar appreciates the kindness and help of Juhyung Lee and all the personnel at Seokguram. Joseph 
Cabeza Lainez dedicates this article to Francisca Lainez Robles. Conflicts of Interest: The authors declare no conflict of interest.

\section{References}

1. Spence: J. D. The Memory Palace of Matteo Ricci; Viking Penguin: New York, United States of America, 1984.

2. Lucena, J. de. Historia Da Vida Do Padre Francisco de Xavier, e Doque Fizerao Na India Os Mais Religiosos Da Companhia de Iesu; Crasbeeck, P., Ed.; Lisboa, Portugal, 1600.

3. Saraiva, L. et al. História Das Ciências Matemáticas: Portugal e o Oriente - History of Mathematical Sciences: Portugal and East Asia; Fundação Oriente, Lisboa, Portugal, 2000.

4. D’Elia, P. M. Fonti Ricciane; Documenti Originali Concernenti Matteo Ricci e La Storia Delle Prime Relazioni Tra l'Europa e La Cina (1579-1615). Libreria dello Stato, Roma, Italy, 1942.

5. $\quad$ Ricci, M. De Christiana Expeditione apud Sinas. Ed. Nicolas Trigault. Augsburg. 1615.

6. He, Z.; Zeng, Z. 圆明园园林艺术 / 何重义, 曾昭奋著 Yuan Ming Yuan Yuan Lin Yi Shu [The Artistic Technique of Yuan Ming Yuan Gardens]; Ke xue chu ban she, Beijing, China, 1995.

7. $\quad$ Bourdon, L. La Compagnie de Jésus et Le Japon: La Fondation de La Mission Japonaise Par François Xavier (1547-1551) et Les Premiers Résultats de La Prédication Chrétienne Sous Le Supériorat de Cosme de Torres (1551-1570); Fondation Calouste Gulbenkian, Lisbon, Portugal, 1993.

8. Boxer, C. R. The Portuguese Seaborne Empire, 1415-1825; History of Human Society; Hutchinson, London, United Kingdom, 1969.

9. Bailey, G. A. Art on the Jesuit Missions in Asia and Latin America, 1542-1773; University of Toronto Press, Toronto, Canada 1999.

10. Cabeza Lainez, J. M. La Visión y La Voz: Arte, Ciudad y Cultura En Asia Oriental; UCOPress Ediciones Universidad de Córdoba, Córdoba, Spain, 2017.

11. Cabeza Lainez, J. M. El Siglo Ibérico de Japón, influencias recíprocas en la formación del Barroco. Tokyo Gaigo Daigaku, Tokyo, Japan, 22 January 2001.

12. Cabezas García, A. El Siglo Ibérico Del Japón: La Presencia Hispano-Portuguesa en Japón (1543-1643); Instituto de Estudios Japoneses, Universidad de Valladolid, Spain, 1995.

13. Cabeza-Lainez, J.M.; Almodóvar-Melendo, J.M. Daylight, Shape, and Cross-Cultural Influences Through the Routes of Discoveries: The Case of Baroque Temples. Space Cult. 2018, 21, 340-357.

14. Almodovar-Melendo, J.M.; Cabeza-Lainez, J.M. Environmental Features of Chinese Architectural Heritage: The Standardization of Form in the Pursuit of Equilibrium with Nature. Sustainability 2018, 10, 2443.

15. Lip, E. Feng Shui - Environments of Power: A Study of Chinese Architecture; Academy Editions, London, United Kingdom, 1995.

16. Valladares, R. Castilla y Portugal En Asia (1580-1680). Declive Imperial y Adaptación. In Castilla y Portugal en Asia (1580-1680); Leuven University Press, Leuven, Belgium, 2001.

17. Azevedo, C. de. The Churches of Goa. J. Soc. Archit. Hist. 1956, 15 (3), 3-6. https://doi.org/10.2307/987759.

18. Salguero Andujar, F.; Rodriguez Cunill, I.; Cabeza-Lainez, J.M. The Problem of Lighting in Underground Domes, Vaults, and Tunnel-Like Structures of Antiquity; An Application to the Sustainability of Prominent Asian Heritage (India, Korea, China). Sustainability 2019, 11, 5865. https://doi.org/10.3390/su11205865

19. Beltrão Coelho, R. Macau Retalhos: Passado, Presente e Futuro; Livros do Oriente: Macau, 1990.

20. Montmignon, J.B. Choix des lettres édifiantes, écrites des missions étrangères. Chez Maradan, Paris, France, 1808.

21. Kircher, A. China Monumentis, qua Sacris Quà Profanis, Nec Non Variis Naturae et Artis Spectaculis, Aliarumque Rerum Memorabilium Argumentis Illustrata; J. Janssonium, Ed. Amsterdam, Netherlands, 1667.

22. Kircher, A. Turris Babel, Sive Archontologia...; Ex Officina Janssonio-Waesbergiana, Amsterdam, Netherlands, 1679.

23. Almodovar-Melendo, J.M.; Cabeza-Lainez, J.M.; Rodríguez-Cunill, I. Lighting Features in Historical Buildings: Scientific Analysis of the Church of Saint Louis of the Frenchmen in Seville. Sustainability 2018, 10, 3552.

24. Guarini, C. G. Euclides Adauctus et Methodicus Mathematicaque Universalis. 1671. Torino (Italy).

25. Beurdeley, C. Giuseppe Castiglione, a Jesuit Painter at the Court of the Chinese Emperors; Charles E. Tuttle Company, Rutland Vt., United States of America, 1971.

26. Wertheim, M. The Pearly Gates of CyberSpace. W.W.Norton. 2000.

27. Pirazzoli-t'Serstevens, M.; Musillo, M. Giuseppe Castiglione, 1688-1766: Peintre et Architecte à La Cour de Chine; Thalia, Paris, France, 2007.

28. Tōyō Bunko. Memoirs of the Research Department of the Toyo Bunko (the Oriental Library); Publications - Tōyō Bunko. Ser. B; The Toyo Bunko, Tokyo, Japan, 1926.

29. Musillo, M. Reconciling Two Careers: The Jesuit Memoir of Giuseppe Castiglione Lay Brother and Qing Imperial Painter. Eighteenth-Century Studies. The John Hopkins University Press American Society for Eighteenth-Century Studies (ASECS) 2008, pp 45-59. https://doi.org/10.1353/ecs.0.0035.

30. Chang, A. I. T.; Cabeza Lainez, J. M. El Dao de La Arquitectura; Comares, Granada, Spain, 2011.

31. Huang, S.; Gong, Y. 利瑪竇世界地圖研究 Li Madou Shijie Ditu Yanjiu [Research on world maps by Matteo Ricci]. Shangai guji chubanshe [Shanghai Ancient Object Publications], 2004. 
32. Cabeza Lainez, J. M. Desde Sri Lanka Hasta Japón: Ideas Acerca de La Evolución Del Stupa. In La investigación sobre Asia Pacífico en España; Colección Española de Investigación sobre Asia Pacífico 1, San Ginés Aguilar, P., Ed.; Universidad de Granada: Granada, Spain, 2007; pp 553-570.

33. Zhewen, L. 中国古园林，羅哲文 Zhongguo Guyuanlin [Ancient Chinese Gardens]; 中国建筑工业出版社 Zhōngguó jiànzhú gōngyè chūbăn shè, Beijing, China,1999.

34. Shu, M.; Shen, W.; He, N. Yuanming Yuan Zilio Ji [Source Materials about the Yuanming Yuan]; Shumu wenxian, Beijing, China, 2004.

35. Bai, J. At the foot of Mount Incense Burner. Retrieved from: Pérez-Rendón, C.A. De profundis, Herramientas de simulación del potencial energético de la tierra en arquitectura. PhD thesis, Universidad de Sevilla, Sevilla, Spain, 22 January 2016.

36. Wu, J. 儒林外史 RuLin WaiShi [Unofficial History of the Scholars].1750. Project Gutenberg, 2007. Available: http://www.gutenberg.org/ebooks/24032.

37. Thucydides. The History of the Peloponnesian War. Pg. 35. Penguin Classics. 1954.

38. Bucci-Glucksmann, C. La raison baroque. De Baudelaire à Benjamin. Paris: Galilée, 1984. 